\title{
Morphological study of the heart of the Indonesian short-nosed fruit bat (Cynopterus titthaecheilus Temminck, 1825)
}

\author{
ANISA RAHMA, DESRAYNI HANADHITA, ANDHIKA YUDHA PRAWIRA, SUPRATIKNO KASMONO, \\ HERA MAHESHWARI, ARYANI SISMIN SATYANINGTIJAS, SRIHADI AGUNGPRIYONO \\ Department of Anatomy Physiology and Pharmacology, Faculty of Veterinary Medicine, Institut Pertanian Bogor. Jl. Agatis, Kampus IPB Dramaga, \\ Bogor 16680, West Java, Indonesia. Tel +62-251-8629469, 8629464, Fax.: +62-251-8629464. `email: ysrihadi@apps.ipb.ac.id, \\ rahmaanisa31@gmail.com
}

Manuscript received: 24 June 2020. Revision accepted: 9 October 2020.

\begin{abstract}
Rahma A, Hanadhita D, Prawira AY, Kasmono S, Maheshwari H, Satyaningtijas AS, Agungpriyono S. 2020. Morphological study of the heart of the Indonesian short-nosed fruit bat (Cynopterus titthaecheilus Temminck, 1825). Biodiversitas 21: 5094-5101. The energy demand of an animal becomes an important factor that affects the adaptation of cardiac or heart anatomy. As the largest Cynopterus bat in Indonesia, Cynopterus titthaecheilus (Temminck, 1825) is one of the flying mammals that need a lot of energy to accommodate its flying activity. This study aims to acknowledge the anatomical adaptation of the heart in C.titthaecheilus, which includes the weight ratio of the heart, heart structure, and primary blood vessel branches. This study conducted of 10 juvenile $C$. titthaecheilus $(56.15 \pm 13.43 \mathrm{~g}), 13$ females $(74.38 \pm 10.34 \mathrm{~g})$, and 18 males $(73.27 \pm 13.54 \mathrm{~g})$. Bats ware killed by ketamine overdoses, then the thoracic cavity was opened and the heart was removed from the thoracic cavity for observation. The results of this study revealed that the ratio of heart mass to body mass of adult female $C$. titthaecheilus was 0.014 , male adult $C$. titthaecheilus was 0.015 and juvenile $C$. titthaecheilus was 0.015 . The heart-shaped was an oval, located in the thoracic cavity, tilted to the left. On the other hand, the heart structure of $C$. titthaecheilus consisted of a thicker left ventricle compared to the right ventricle, but the musculi pectinati, musculus papillaris, and trabecula septomarginalis were well developed on the right side of the heart compared to the left side. Subsequently, the branches of the primary blood vessels in the heart consisted of an aortae ascendens, three arteria pulmonalis dextra and one arteria pulmonalis sinistra, a vena pulmonalis, the vena cava anterior dextra et sinistra, and a single vena cava posterior. In addition, the conus arteriosus, which is an enlarged space of the pulmonary artery, was observed in a large size. Based on this study, it was concluded that the heart structure of $C$. titthaecheilus was very important in supporting their ability to fly.
\end{abstract}

Keywords: Heart anatomy, heart mass ratio, trabecula septomarginalis, vena cava anterior sinistra

\section{INTRODUCTION}

The heart is the main organ of the cardiovascular system that acts as a pump to drain blood throughout the body (Reece et al. 2014). Generally, the heart of a mammal has four chambers consisting of two atria and two ventricles, as well as large arteries and veins. Although in general, the structure of the heart is similar, but the anatomical details of the heart can be different between each family or ordo (Jensen et al. 2012; Mavrodi and Paraskevas 2014). Morphological and anatomical adaptations of the heart are influenced by the process of evolution and energy demands of an animal (Jensen et al. 2012).

The heart performance must be consistent with the body's oxygen consumption, resulting in size of the heart varies between species, which can be shown as the ratio of heart weight to body (Verhoeff and Mitchell 2017). According to empirical studies of cardiovascular variables, it is known that cardiac mass is an appropriate indicator for the level of adaptive specialization of prolonged locomotor activity, both in birds and mammals (Bishop 1997). Bats represent the only mammal that is able to fly. As an athletic animal that relies on flying to survive, bats rely on the cardiovascular system to be able to distribute oxygen quickly. This is because bats do not have other blood distribution support systems such as the spleen which do not have extensive muscularization as do other athletic animals namely horses and race dogs (Hanadhita et al. 2019; Hanadhita et al. 2020). Adaptation of the bat's cardiovascular system aims to meet requires oxygen consumption during flight. Bats have a respiratory and cardiovascular system that has been designed to meet their oxygen needs when flying or resting, including a large heart; high percentage of hematocrit, high concentration of hemoglobin, high amount of erythrocytes, and efficient blood supply to the flying muscles (Schinnerl et al. 2011; Rahma et al. 2017).

The studies of the heart anatomy of bat have been reported, such as in Eidolon helvum (Rowlatt 1967), Nyctophillus sp. (Bullen et al. 2010), and Rousettus aegyptiacus (Alijani and Ghassemi 2016) which revealed a variation between species in Chiroptera ordo. Cynopterus titthaecheilus (Temminck, 1825) is one of the fruit-eater bats in Pteropodidae ordo and the largest Cynopterus bat in Indonesia (Suyanto 2001). As an endemic bat in Indonesia, the data about $C$. titthaecheilus are very few, especially in the cardiovascular system. The data of the anatomical structure of the heart of $C$. titthaecheilus can enrich scientific data on Indonesian animals and support 
conservation activities or other research.

\section{MATERIALS AND METHODS}

\section{Bat capture and identification}

Bats were captured in the area of IPB University campus with a mist net under permission from the Ministry of Environment and Forestry, Department of Natural Resource and Ecosystem Conservation, Indonesia, with license numbers SK.197/KSDAE/SET/KSA.2/5/2017. All the captured bats were then acclimatized for 24 hours in a $1 \times 1 \times 1 \mathrm{~m}^{3}$ cage and fed with fruit and ad libitum water. The bats were anesthetized using a combination of ketamine $\mathrm{HCl}(10 \mathrm{mg} / \mathrm{BW})$ and xylazine $\mathrm{HCl}(2 \mathrm{mg} / \mathrm{BW})$ (Sohayati et al. 2008). The anesthetized bat then proceeded to physical examination and measurement of body weight and morphometry for species identification that conducted according to Suyanto (2001). Adult female bats and juvenile bats could be differentiated by observing the vaginal opening, while the adult male could be recognized from a descending testicle. In this study, the $C$. titthaecheilus that used consisted of 10 juvenile bats $(56.15 \pm 13.43 \mathrm{~g}), 13$ females $(74.38 \pm 10.34 \mathrm{~g})$, and 18 males $(73.27 \pm 13.54 \mathrm{~g})$. All the procedures were done according to the ethical clearance of the University (no 75-2017 IPB).

\section{Anatomical observation}

Anesthetized bats were killed by ketamine overdoses. Furthermore, the tapping is performed in the thorax to observe the position of the heart inside the situs viscerum, which includes the heart and blood vessels' branches. The heart was removed and measurements were done on the weight, height, and length. Then the heart was fixed in Bouin's solution to further observations of the internal part of the heart. Arteries and veins can be distinguished macroscopically by looking at the wall thickness and lumen shape. Venous lumen looks irregular while arterial lumen is circular. The anatomical data were documented using photographs and presented descriptively.

\section{RESULTS AND DISCUSSION}

\section{Results}

The heart was located in the thoracic cavity along with lungs. The heart was covered by a thin, strong, and clear pouch, the pericardium, which bordered with diaphragm in caudal part, adventisia, and fascia of trachea in cranial part. Moreover, the middle part of the pericardium is attached to the os sternum by lig. sternopericardiacum. Cynopterus titthaecheilus heart was an oval-shaped with dark red color, located ventrally in the thoracic space between intercostal spaces IV to intercostal spaces IX. The apex was narrow and tilted to the left, resulting in almost part of the heart laying in the left side. Subsequently, the heart formed a $45^{\circ}$ angle to the left side with esophagus and trachea as the axis (Figure 1).

Generally, the heart of $C$. titthaecheilus was observed to be bigger in adult males compared to the adult female and juvenile bat. This was correlated to the higher heart mass in male adult bat compared to the adult female and juvenile bat. Moreover, these data result in a higher ratio of heart mass to body mass in the adult male compared to the adult female (Table 1).

The branches of the blood vessels that enter and exit of the heart are presented in Figure 2. The aortae ascendens came out from the left ventricle and form a curvature, namely arcus aortae, which is directed to the caudal of the body namely aortae descendens, which branched into arteries in the lower body. In addition, the arcus aortae branched into several arteries to the upper body, namely the arteria brachiocephalica, arteria subclavia sinistra, and arteria carotis communis sinistra. Moreover, the arteria brachiocephalica branched into the arteria subclavia dextra and the arteria carotis communis dextra.

The heart of $C$. titthaecheilus possessed two vena cava anterior, namely vena cava anterior sinistra et dextra. The vena cava anterior sinistra traveled around the dorsal part of the heart before entered the right atrium. On the other hand, the vena cava anterior dextra directly entered the right atrium by forming a vertical $90^{\circ}$ angle. The vein that drains the blood from lower body, the vena cava posterior, traveled straight from the caudal part then entered the right atrium. The vena cava anterio dextra and vena cava posterior share the same opening into a single ostium, while the vena cava anterior sinistra entered into right atrium in the separate ostium.

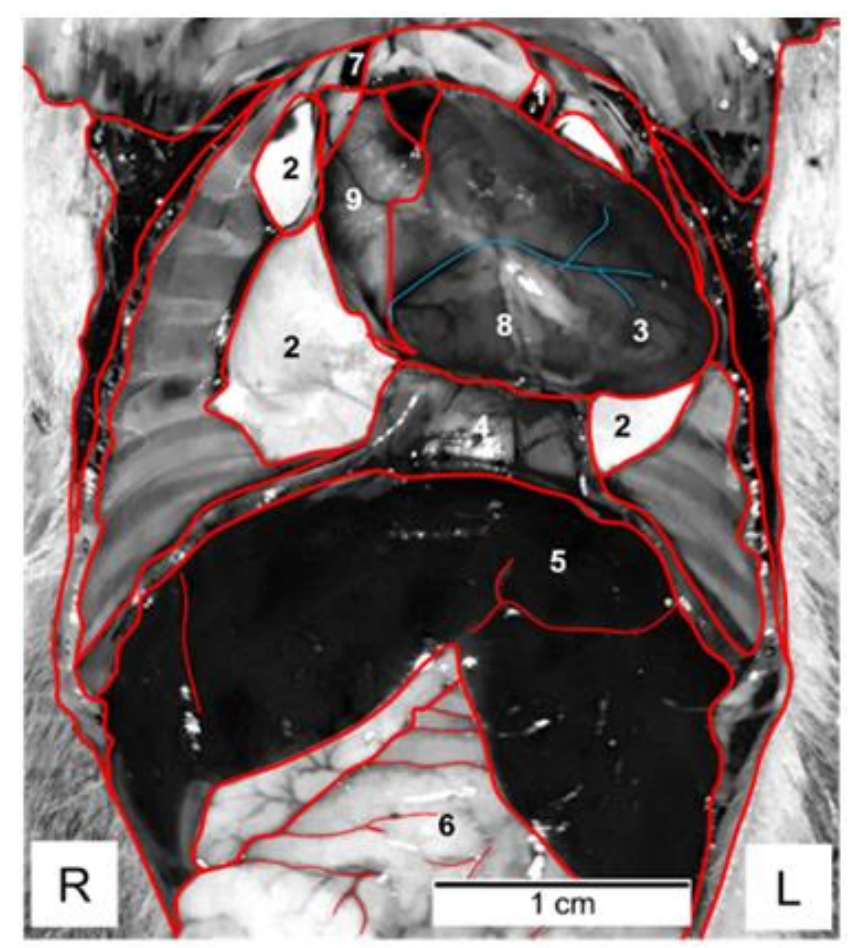

Figure 1. Position of Cynopterus titthaecheilus heart in the thoracic cavity. right/dextra (R), left/sinistra (L), arteria pulmonalis (1), lungs (2), left ventricle (3), diaphragm (4), liver (5), small intestine (6), vena cava anterior dextra (7), right ventricle (8), right atrium (9). 
Tabel 1. Morphometric of Cynopterus titthaecheilus heart

\begin{tabular}{llcc}
\hline \multirow{2}{*}{ Parameter } & \multirow{2}{*}{ Juvenile } & Male & Adult \\
\cline { 2 - 4 } & & $1.797 \pm 0.21$ & $1.719 \pm 0.13$ \\
Length $(\mathrm{cm})$ & $1.607 \pm 0.17$ & $0.722 \pm 0.28$ & $0.741 \pm 0.16$ \\
Widht $(\mathrm{cm})$ & $0.691 \pm 0.13$ & $1.078 \pm 0.23$ & $1.031 \pm 0.24$ \\
Heart mass $(\mathrm{g})$ & $0.860 \pm 0.19$ & $73.27 \pm 13.54$ & $74.38 \pm 10.34$ \\
Body mass $(\mathrm{g})$ & $56.15 \pm 13.43$ & 0.015 & 0.014 \\
Ratio of HM/BM $(\mathrm{g} / \mathrm{g})$ & 0.015 & $2.48 \pm 0.41$ & $2.34 \pm 0.17$ \\
Left ventricle, LV(mm) & $2.46 \pm 0.2$ & $1.27 \pm 0.18$ & $1.21 \pm 0.13$ \\
Right ventricle, RV $(\mathrm{mm})$ & $1.2 \pm 0.13$ & 2.00 & 1.94 \\
Ratio LV : RV & 1.92 & & \\
\hline
\end{tabular}
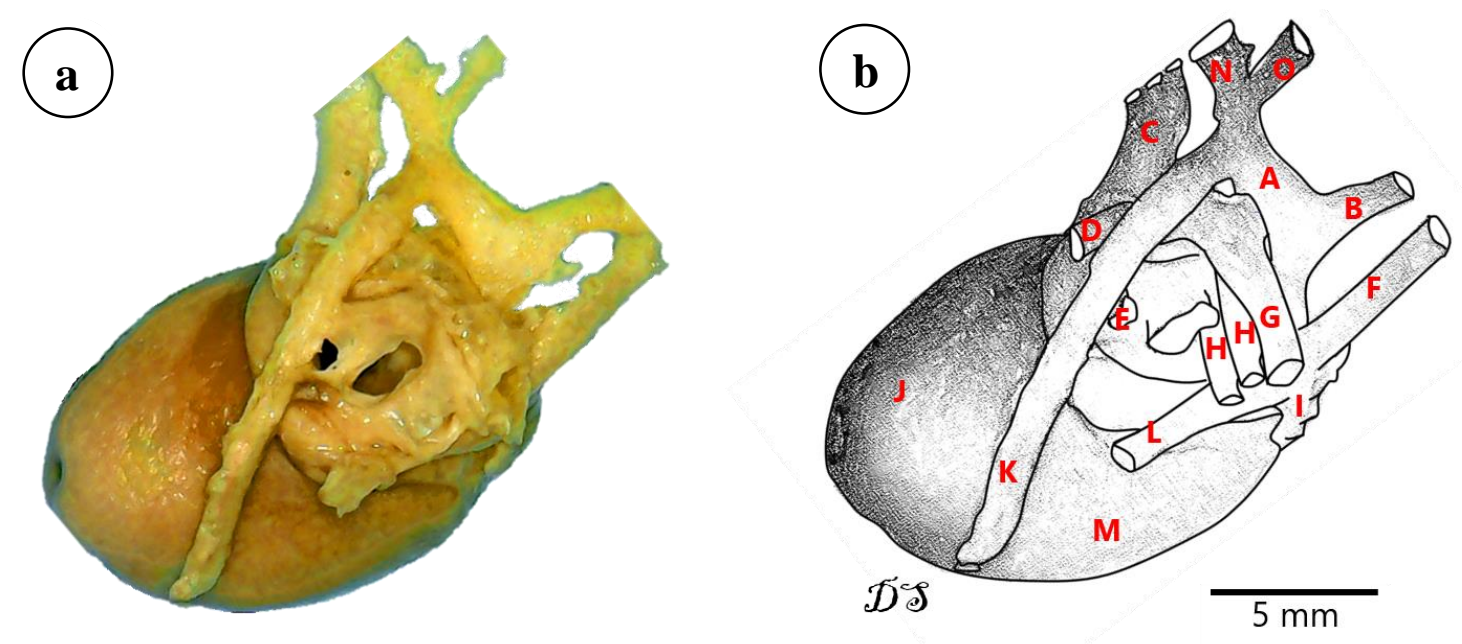

Figure 2. Dorsal view of Cynopterus titthaecheilus heart shows blood vessels branches (a) and its schematic drawing (b). arcus aortae (A), arteria brachiocephalica (B), vena cava anterior sinistra (C), arteria pulmonalis sinistra (D), vena pulmonalis sinistra (E), vena cava anterior dextra $(\mathrm{F})$, arteria pulmonalis dextra $(\mathrm{G})$, vena pulmonalis dextra $(\mathrm{H})$, right atrium $(\mathrm{I})$, left ventricle $(\mathrm{J})$, Aortae $(\mathrm{K})$, vena cava posterior $(\mathrm{L})$, right ventricle $(\mathrm{M})$, arteria subclavia sinistra $(\mathrm{N})$, arteria carotis communis sinistra $(\mathrm{O})$

The sulcus interventricularis subsinosus were observed in the caudoventral side of the left ventricle, traveling from the base of the heart and ended in the dorsal part of the apex (Figure 3). Moreover, in the base of the ventral part of the right ventricle, a protrusion was observed, namely conus arteriosus, which branched out arteria pulmonalis. The arteria pulmonalis branched into the arteria pulmonalis sinistra et dextra, which was observed to be larger in the arteria pulmonalis dextra compared to the arteria pulmonalis sinistra. On the other hand, interestingly, a single vena pulmonalis sinistra and three vena pulmonalis dextra merged in one ostium before entering the left atrium (Figure 2). The right and left ventricle were separated by sulcus interventricularis paraconalis (Figure 4), which run from the caudal part of conus arteriosus to the apex cordis. The size of the conus arteriosus was quite large and dominant, thus retained almost half of the right atrium. The left atrium had a smaller size and thinner wall compared to the right atrium. The general structure of the $C$. titthaecheilus heart is shown in Figure 5.

The wall of the left ventricle was nearly twice as thick as the wall in the right ventricle (Table 1). Generally, the thickness of the ventricle wall in the adult male is higher compared to that of the adult female, but smaller for the right ventricle if compared to the juvenile bats. Bicuspidalis valves were observed to border the chambers between the left atrium and left ventricle, while the tricuspidalis valves were found between the right atrium and right ventricle (Figure 6). The valves that were observed constitute a thin and transparent membrane. This structure was connected to the thin fiber, namely the chordae tendineae, which is attached to the Musculus papillaris in the heart wall. M. papillaris in the left ventricle was smaller compared to in right ventricle. In addition, the right ventricle was connected to the interventricular septum through trabecula septomarginalis (Figure 6).

The right atrium was located above the right ventricle and became a place for the vena cava posterior and vena cava anterior sinister et dexter. The inner part of the right atrium had the crest of the musculi pectinati (Figure 7). On the other hand, the left atrium had a thin wall and became a place for vena pulmonalis. The left atrium was much smaller than the right atrium, thus, the latter was unable to be dissected for observation. 

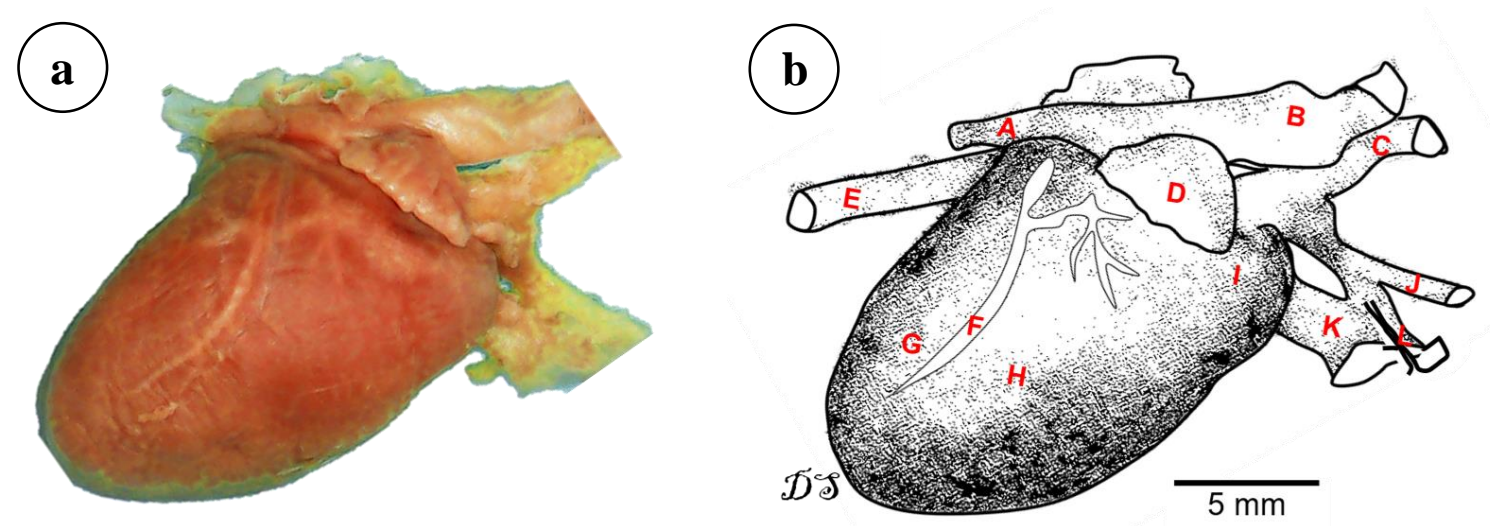

Figure 3. Ventrolateral view of Cynopterus titthaecheilus heart shows the location of sulcus interventricularis subsinosus (a) and its schematic drawing (b). vena cava posterior (A), vena cava anterior dextra (B), arteria brachiocephalica (C), right atrium (D), aortae (E), sulcus interventricularis subsinosus $(\mathrm{F})$, right ventricle $(\mathrm{G})$, right ventricle $(\mathrm{H})$, conus arteriosus $(\mathrm{I})$, arteria carotis communis sinistra $(\mathrm{J})$, vena cava anterior sinistra $(\mathrm{K})$, arteria subclavia sinistra $(\mathrm{L})$.
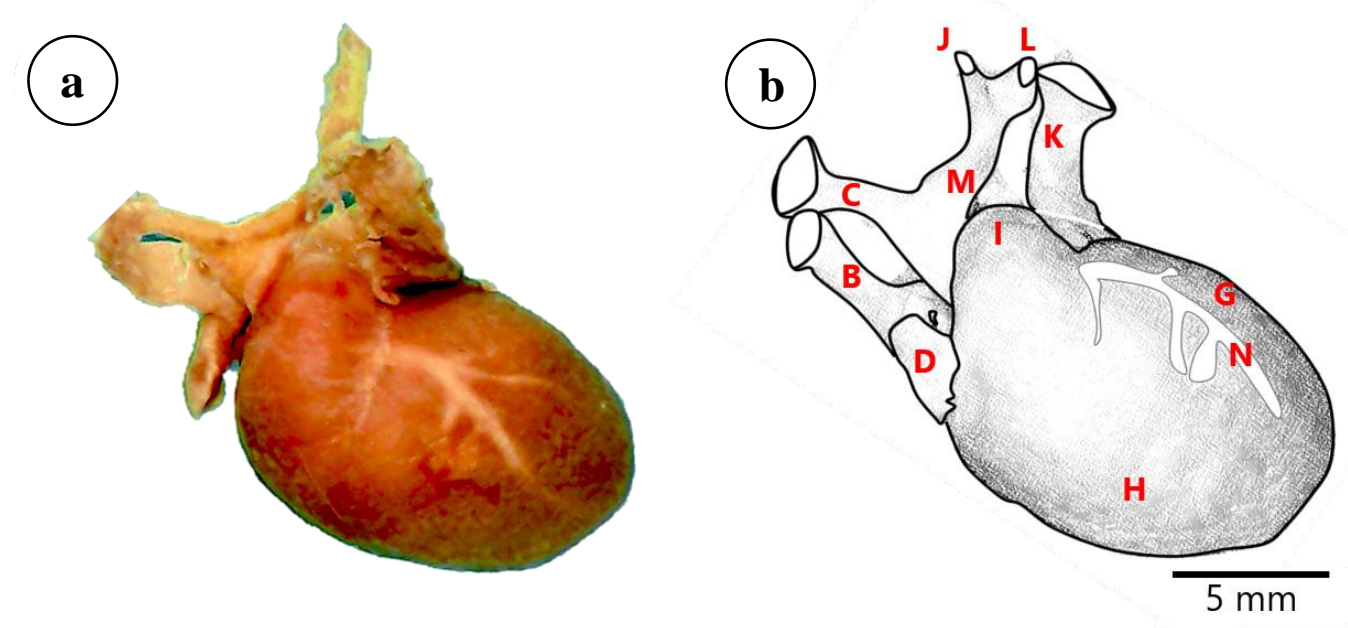

Figure 4. Ventral view of Cynopterus titthaecheilus heart shows the location of sulcus interventricularis paraconalis (a) and its schematic drawing (b). arcus aortae (A), arteria brachiocephalica (B), vena cava anterior sinistra(C), left ventricle (D), conus arteriosus $(\mathrm{E})$, vena cava anterior dextra $(\mathrm{F})$, right atrium $(\mathrm{G})$, sulcus interventricularis paraconalis $(\mathrm{H})$, right ventricle $(\mathrm{L})$, arteria carotis communis sinistra $(\mathrm{K})$, arteria subclavia sinistra $(\mathrm{L})$

\section{Discussion}

The anatomical structure of the heart can reflect adaptation of the cardiovascular system in an animal to the activity and oxygen demand. Generally, the position of the C. titthaecheilus heart in the thoracic cavity is similar to that of some other mammals it is, in the middle, tilted to the left such as mice, rat, rabbit, and human (Stephenson et al. 2017). Differences in body posture of bats with four-legged terrestrial mammals also cause differences in the location of the heart in the thorax cavity. Generally, the position of the heart apex in four-legged terrestrial mammals tend to lead to the ventral part, because of the gravitational force (Stephenson et al. 2017), whereas in bats, that position tends situated in the middle of thorax cavity with anterioposterior orientation. This may be related to the normal body position of a bat that hangs upside down when resting
(Riskin et al. 2009; Ashaolu and Ajao 2014), as an adjustment to the connective tissue that supports the position of the heart in the proper orientation. The pericardium and the connective tissue that connects the heart to the surrounding organs are a major part of this adaptation. Pericardium is known to have several functions, such as preventing heart from dilating, protecting it from infection, fixing the heart with surrounding tissues, and also keeping it in a fixed position in the thorax cavity. Another function is to regulate the associated of stroke volume between two ventricles (Volpe and Makaryus 2019). The position of $C$. titthaecheilus heart is same as the heart position of Rousettus aegypticus bats, which have smaller body weights than $C$. titthaecheilus (Alijani and Ghassemi 2016). 


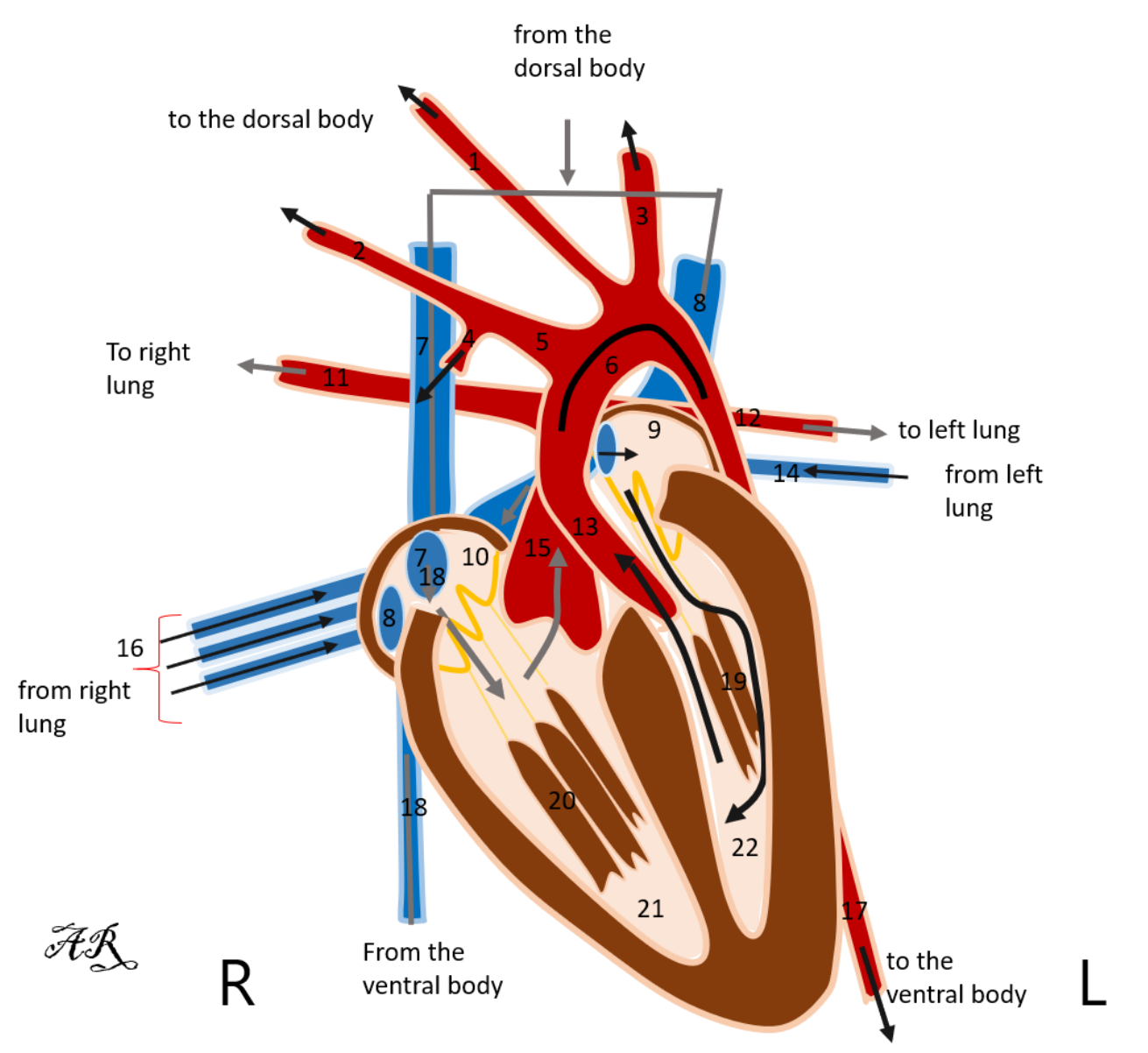

Figure 5. Schematic drawing of the heart structure and blood vesells branches of Cynopterus titthaecheilus. The veins were shown in blue color, and arteries were showed in red color. Grey arrow indicated poor-oxygenated blood while black arrow indicated richoxygenated blood. right/dextra (R), left/sinistra $(\mathrm{R})$, arteria carotis communis sinistra (1), arteria carotis communis dextra (2), arteria subclavia sinistra (3), arteria subclavia dextra (4), arteria brachiocephalica (5), Arcus aortae (6), vena cava anterior dextra (7), vena cava anterior sinistra (8), left atrium (9), right atrium (10), arteria pulmonalis dextra(11), arteria pulmonalis sinistra (12), Aortae ascendens (13), vena pulmonalis sinistra(14), conus arteriosus (15), vena pulmonalis dextra (16), Aorta descendens (17), vena cava posterior (18), M. papillaris left ventricle (19), M. papillaris right ventricle (20), right ventricle (21), left ventricle (22).
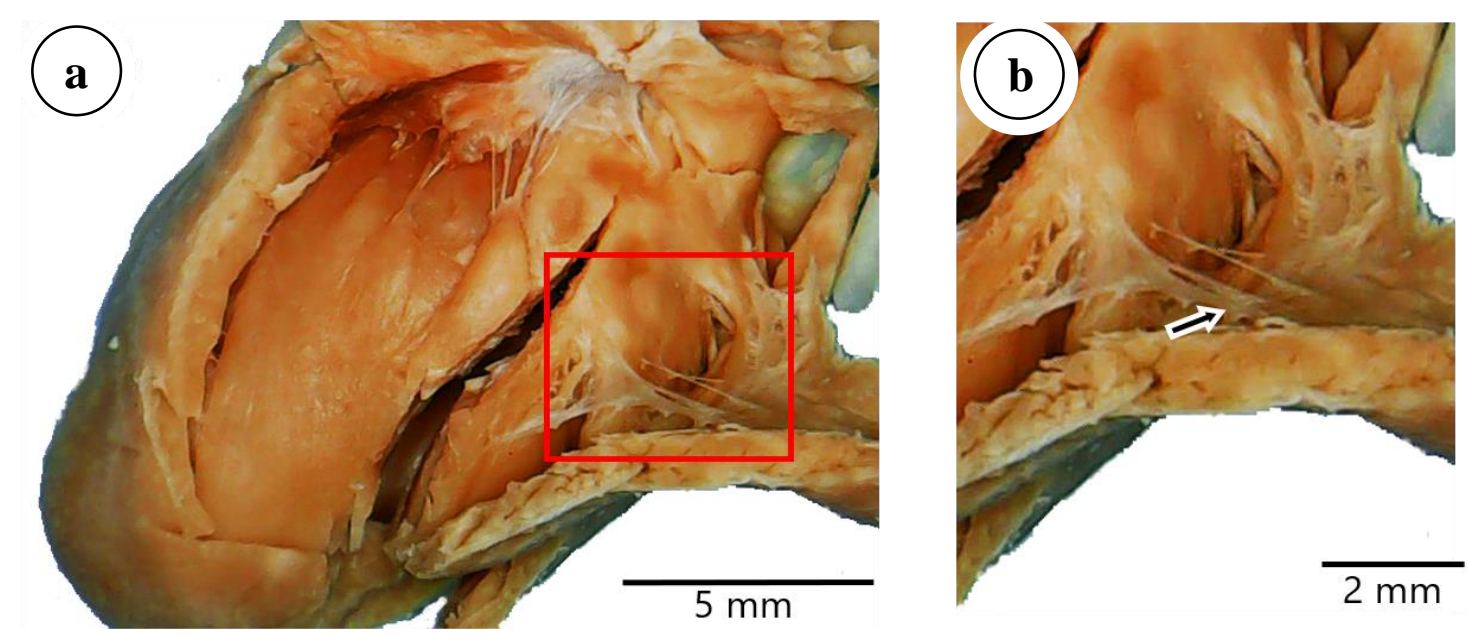

Figure 6. The internal structure of Cynopterus titthaecheilus heart. The right ventricle (a), and trabecula septomarginalis was indicated by black arrow (b) 

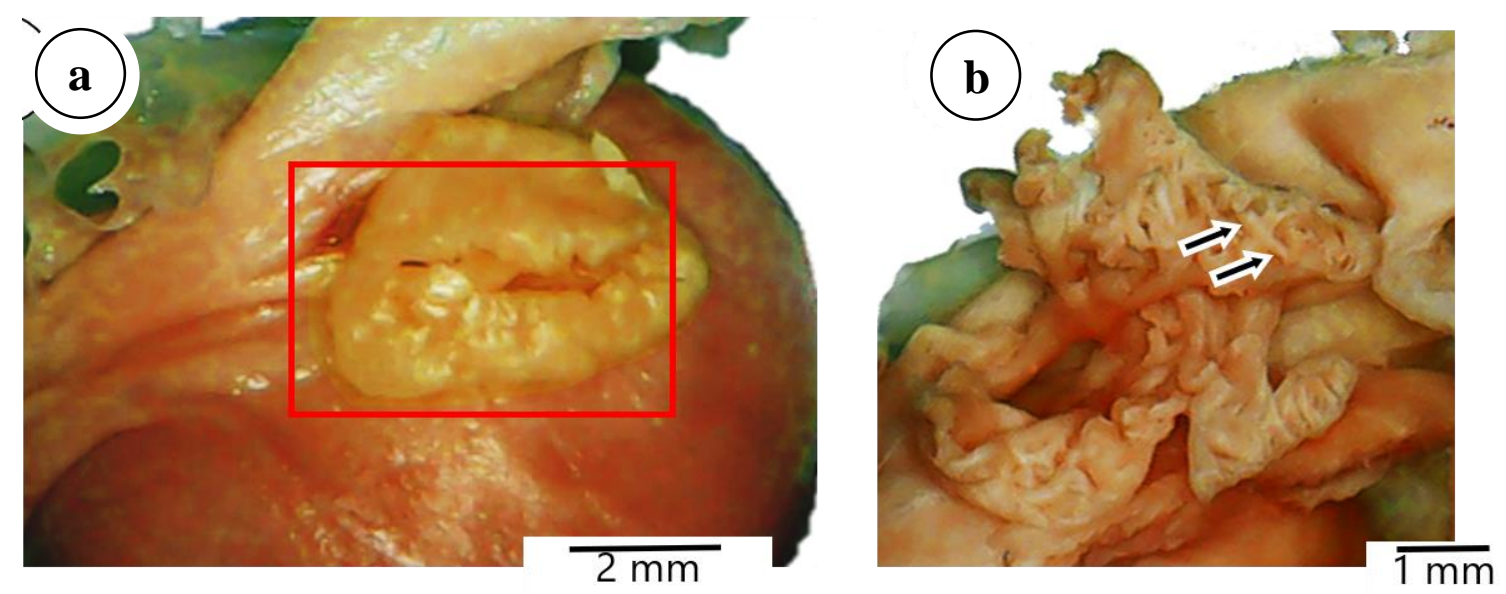

Figure 7. The internal structure of the Cynopterus titthaecheilus heart. The right atrium of the heart was shown in red rectangle (a), while $\mathrm{mm}$. pectinati in the atrium were shown in black arrows (b)

One of the basic parameter that determines the functional efficiency of the heart is the heart mass. Most researchers found a correlation between the heart and body weight. There are two main factors responsible for this adaptation, which are increased energy requirements to stabilize body temperature in homeotherms, and energy requirements for resist gravity (such as in birds and bats) (Busse et al. 2013; Shave et al. 2017). Generally, active animals have a greater heart mass compared to less active animals. Flying activity in birds and bats causes the flight muscles to require a large amount of energy against gravity so that it has an impact on the large heart mass. If there is a change in the ratio of heart mass to body mass, it may be related to an increase in the heart mass caused by a combination of heart hypertrophy and hyperplasis or a decrease in the body mass (Ostadal and Dhalla 2013). This was observed in juvenile $C$. titthaecheilus, which tended to have a higher heart mass ratio rather than adult female $C$. titthaecheilus due to the body mass of juvenile bats was lower than the adult bats.

Research conducted by Bullen et al. (2010), showed a correlation between heart mass with their habitat and bat foraging niches. Bats that are active on the surface and hoover actively in foraging, such as Nyctophillus sp. will have a higher heart mass ratio than bats that live in caves such as Vespadelus finlaysoni (Bullen et al. 2010). C. titthaecheilus have a greater heart mass ratio (0.015) than Nyctophillus sp. (0.005) reported by Bullen et al. (2010) thus indicating that the role of the heart at $C$. titthaecheilus is greater and influences its ability to hoover for foraging.

The blood vessels that come out of the heart play a role as a tunnel that drains the blood from and throughout the body. Generally, the aortae and arteria pulmonalis play the role in carrying blood from outside the heart while the vena cava and vena pulmonalis act to drain the blood to the heart. This study showed that the arcus aortae of $C$. titthaecheilus had similarities with the arcus aortae in mole-rat (Aydin et al. 2013) which have 3 branches, namely arteria brachiochepalica, arteria subclavia sinistra, and arteria carotis communis sinistra. In addition, one of the uniqueness of $C$. titthaecheilus is the presence of the vena cava anterior sinistra, which is also found in bats Eidolon helvum (Rowlatt 1967) and R. aegyptiacus (Alijani and Ghassemi 2016). The presence of the vena cava anterior sinistra, has been considered as one of the special features of the rodent circulatory system, such as mice, rat, and rabbit (Kresakova et al. 2015). This is probably one of the uniqueness in variations of the cardiovascular system in bats. Although $C$. titthaecheilus has similarity in vena cava branches with $E$. helvum and $R$. aegyptiacus, but the number of ostium is different. Eidolon helvum has three ostium from three vena cava (Rowlatt 1967), whereas $R$. aegyptiacus has two ostium (Alijani and Ghassemi 2016). The presence of two ostium in $R$. aegyptiacus is the same as those found in C. titthaecheilus. The vena cava anterior sinistra et dextra of $R$. aegyptiacus entered the right atrium by one ostium and vena cava posterior with the different ostium, but the vena cava anterior sinistra et dextra in $C$. titthaecheilus entered the right atrium with a different ostium. The vena cava anterior dextra merged with the vena cava posterior before entered the right atrium. This is can be the unique variation in vena cava of the $C$. titthaecheilus.

The number of vena pulmonalis that carry oxygenated blood from the lungs to the left atrium varies between species, such as humans have two pairs on the left and right, pigs have 7 veins, while bats have three veins, two vena pulmonalis dextra, and one vena pulmonalis sinistra (Rowlatt 1967; Vandecasteele et al. 2013; KlimekPiotrowska et al. 2016). Variations in the number of vena pulmonalis may be related to the amount of blood flow carried by blood vessels from one part of the body. In the heart of $C$. titthaecheilus, the vena pulmonalis dextra are more numerous than the vena pulmonalis sinistra. It is possible that the blood supply from the right lung is more than the left lung. This happens because the size of the left lung is much smaller than the right lung. The small size of the left-right due to most of the left thoracic space is 
occupied by the heart. Furthermore, the vena pulmonalisof C. titthaecheilus joins to form a single vein before entering the left atrium. In $R$. aegyptiacus, the vena pulmonalis sinistra et dextra entered the left atrium via two separate openings. The presence of variation in the ostium of vena pulmonalis may be characteristics of each species.

In general, the arteria brachiochepalica, arteria carotis communis, and arteria subclavia diameter will decrease compared to the diameter of aortae because of branching that has to adjust the blood pressure passing through the blood vessels, so that the diameter of aortae descendens becomes smaller than the aortae ascendens (Reece et al. 2014). Distinct things are found in the vena cava, where the diameter of the vena cava anterior is greater than the vena cava posterior. Generally, in humans, the diameter of the vena cava anterior is smaller than that of the vena cava posterior, which is related to the amount of blood carried by both blood vessels (Kutty et al. 2014). The immense size of the vena cava anterior is relative to the vena cava posterior, which reflects the larger size of the upper limbs. Here, a primitive vascular arrangement has been retained to serve a specialized function as part of the overall modification of the upper limbs for flight (Rowlatt 1967). This correlates with the bat's upper part of body shape which is highly developed into the wings and muscles that support the movement of the wings compared to the smaller lower body, where the hip and leg muscles do not well develop (Suyanto 2001). Large vena cava anterior diameters in bats, especially in $C$. titthaecheilus, indicate that the distribution of blood from the front or upper body is more than that of the back or lower body.

The heart of bats, including C. titthaecheilus is known to have a specific characteristic, which is the large structure of conus arteriosus (Rowlatt 1967). Conus arteriosus is a cone-like enlargement that has a smooth surface. Conus arteriosus functions to minimize pressure fluctuations and regulates the flow of blood out of the ventricles (Lorenzale et al. 2018).

Generally, the blood pressure in systemic blood flow is higher than the pulmonary blood flow, so that the workload on the left ventricular is greater than that of the right ventricle (Reece et al. 2014). The left ventricle plays a role in pumping blood from the heart to the entire body while the right ventricle pumps blood into the lungs. Therefore, the muscles wall of left ventricle becomes thicker than the right ventricle as it develops. The closing of the ductus arteriosus after birth results in only smaller circulation being pumped by the right ventricle, so the systemic load moves to the left ventricle. This process is seen by increasing the wall thickness of the left ventricle faster than the right ventricle (Latimer 1965). The left being thicker, is more powerful to pump the blood with more force and more rapidly.

Adaptation of the conduction system to the heart plays a role in generating electrical impulses, which is very important in producing heartbeats. Macroscopically, the presence of trabecula septomarginalis can be observed which is a part of the heart's conduction system that transmits impulses from the septum interventricularis to the ventricle. The transmission of these impulses causes the ventricular muscles to contract, so that blood is pumped out of the heart (Abouezzeddine et al. 2010; Ates et al. 2017; Goli et al. 2014). In addition, trabecula septomarginalis also has a role in preventing excessive ventricular expansion during the systole stage. $C$. titthaecheilus has a branched type of trabecula septomarginalis, which connects the septum interventricularis and right ventricle that differs from that found in other animals such as cattle (Nascimento 2019), pigs (Ates et al. 2017; Gulyaeva 2012), dogs (Bombonato 2012; Cope 2015 ), camels (Ghonimi 2014) and buffalo (Ghonimi 2015); most of them have a single trabecula septomarginalis, but ostrich has variation number trabecula septomarginalis (Tadjalli et al. 2009). According to its role in transmitting electrical impulses and preventing excessive expansion of the ventricular wall, the branches trabecula septomarginalis owned by bats, are assumed as an effort to adapt the bat's heart to be able to work harder in meeting the needs of blood flow when flying.

Cardiac activity involving rhythmic contractions (systole) and relaxation (diastole) requires adaptation to prevent excessive distention when receiving blood from the body's circulation. M. papillaris, mm. pectinati, and trabecula septomarginalis are the structures that play a role in maintaining the structure of the heart, thus preventing excessive distension. The high distention burden on the right heart due to receiving blood from the whole body, except the lungs, makes those three compartments develop better in the right atrium and ventricle than the left (Perez et al. 2017).

In conclusion, flying activity causes the heart mass ratio of $C$. titthaecheilus to be greater than that of other terrestrial mammals. In addition, $C$. titthaecheilus has a larger aortae ascendens than the aortae descendens members size, two vena cava anterior, and one vena cava posterior, with a larger diameter than the vena cava posterior. Conus arteriosus of $C$. titthaecheilus is quite large and a branching arteria pulmonalis. The size of the arteria pulmonalis dextra is greater than the arteria pulmonalis sinistra. There are three vena pulmonalis dextra and one vena pulmonalis sinistra. The wall thickness of the left ventricle is nearly twice that of the right ventricle wall. A well-developed $\mathrm{mm}$. pectinati, $M$. papillaris, and trabecula septomarginalis were all found in the right side of the heart compared to the left side, both in the atrium and ventricle. The overall structure of the bat's heart gives the bat's heart the ability to work more optimally in meeting the energy needs of a large bat for flying activities.

\section{ACKNOWLEDGEMENTS}

This study was partly supported by the Ministry of Research, Technology and Higher Education of the Republic of Indonesia through PMDSU (Pendidikan Magister menuju Doktor untuk Sarjana Unggul) scholarship program No. 1049/IT3.11/LT/2017. We also thank Dwi Setiawan for excellent schematic drawings. 


\section{REFERENCES}

Abouezzeddine O, Sulaiman M, Buescher T, Kapa S, Friedman P, Jahangir A, Hammill SC, Packer DL, Asirvatham SJ. 2010. Relevance of endocavitary structures in ablation procedures for ventricular tachycardia. J Cardiovasc Electrophysiol 21 (3): 245-254.

Alijani B, Ghassemi F. 2016. Anatomy and histology of the heart in Egyptian fruit bat (Rousettus aegyptiacus). J Entomol Zool Stud 4 (5): 50-56.

Ashaolu JO, Ajao MS. 2014. Cardiac adaptation in prolonged inverted bats (Eidolon helvum). Eur J Anat 18 (4): 283-290.

Ates S, Karakurum E, Takci L, Basak F, Kurtul I. 2017. Morphology of the atrioventricular valves and related intraventricular structures in the wild pig (Sus scrofa). Folia Morphol 76 (4): 650-659.

Aydin A, Ozkan ZE, Ilgun R. 2013. The morphology of the arteries originating from the arcus aortae and the branches of these arteries in mole-rats (Spalax leucodon). Vet Med 58 (7): 373-376.

Bishop CM. 1997. Heart mass and the maximum cardiac output of birds and mammals: Implications for estimating the maximum aerobic power input of flying animals. Phil Trans R Soc Lond B 352 (1352): 447-456.

Bombonato PP, Mariana ANB, Borelli V, Agreste F, Nascimento LG, Leonardo AS. 2012. Morphometric study of trabecula septomarginalis in dogs. Ars Vet 28 (4): 250-254

Bullen RD, McKenzie NL, Bullen KE, Williams MR. 2010. Bat heart mass: correlation with foraging niche and roost preference. Aust J Zool 57 (6): 399-408. DOI: 10.1071/ZO09053

Busse RV, Swarts SM, Voigt CC. 2013. Flight metabolism in relation to speed in Chiroptera: Testing the U-shape paradigm in the short-tailed fruit bat Carollia perspicillata. J Exp Biol 216 (11): 2073-2080.

Cope LA. 2015. Morphological variations in the Canine (Canis familiaris) right ventricle trabecula septomarginalis dextra and a proposed classification scheme. Anat Histol Embryol 45 (6): 437-442.

Ghonimi W, Abuel-Atta AA, Bareedy MH, Balah A. 2014. Gross and microanatomical studies on the moderator bands (septomarginal trabecula) in the heart of mature Dromedary camel (Camelus dromedaries). J Adv Vet Anim Res 1 (2): 24-31.

Ghonimi WAM, Elbaz A, Ibrahim L, Khair NSB, Emam H, Hellal A. 2015. Moderator bands (trabecula septomarginalis) of Mature Buffalo (Bos bubalis L) with special emphasis on the structure and distribution of the purkinje cardiomyocytes: Histological and histochemical. Cell Dev Biol 4: 3. DOI: 10.4172/2168-9296.1000165.

Goli AK, Kaszala K, Osman MN, Lucke J, Carrilla R. 2014. Chest pain associated with moderator band pacing. Tex Heart Inst J 4 (5): 551 554

Gulyaeva AS, Roshchevskaya IM. 2012. Morphology of moderator bands (septomarginali trabecula) in porcine heart ventricles. Anat Histol Embryol 41 (5): 326-332

Hanadhita D, Rahma A, Prawira AY, Mayasari NLPI, Satyaningtijas AS, Hondo E, Agungpriyono S. 2019. The spleen morphophysiology of fruit bats. Anat Histol Embryol 48 (4): 315-324. DOI: 10.1111/ahe.12442

Hanadhita D, Rahma A, Wahid MR, Mayasari NLPI, Satyaningtijas AS, Hondo E, Agungpriyono S. 2020. Extracellular matrix composition of different spleen compartments of fruit bats. Anat Histol Embryol 49 (2): 281-289. DOI: $10.1111 /$ ahe.12526

Jensen B, Wang T, Christoffels VM, Moorman AFM. 2012. Evolution and development of the building plan of the vertebrate heart. Biochim Biophys Acta (BBA) - Mol Cell Res 1833 (4): 783-794

Klimek-Piotrowska W, Holda MK, Piatek K, Koziej M, Holda J. 2016. Normal distal pulmonary vein anatomy. Peer J 4: e1579. DOI: 10.7717/peerj.1579.

Kresakova L, Purzyc H, Schusterova I, Fulton B, Maloveska M, Vdoviakova K, Kravcova Z, Boldizar M. 2015. Variability in the cardiac venous system of Wistar Rat. J Am Assoc Lab Anim Sci 54 (1): 10-16.

Kutty S, Li L, Hasan R, Peng Q, Rangamani S, Danford DA, Omaha, Nebraska. 2014. Systemic venous diameters, collapsibility indices, and right atrial measurements in normal pediatric subjects. J Am Soc Echocardiography 27 (2): 155-162.

Latimer HB. 1965. The weight and thickness of the two ventricular walls in the newborn dog heart. Anat Rec 152 (2): 225-230. DOI: 10.1002/ar.1091520214

Lorenzale M, Unzu MAL, Rodríguez C, Fernández B, Durán AC, Coma VS. 2018. The anatomical components of the cardiac outflow tract of chondrichthyans and actinopterygians. Biol Rev 93 (3): 1604-1619.

Mavrodi A, Paraskevas G. 2014. Morphology of the heart associated with its function as conceived by ancient Greeks. Intl J Cardiol 172 (1): 23-28. DOI: 10.1016/j.ijcard.2013.12.124

Nascimento SRR, Ruiz CR, Olivia SU. 2019. Histological and anatomical variations of septomarginal trabecula in bovine hearts. Anat Histol Embryol 48 (3): 228-233.

Ostadal B, Dhalla NS. 2013. Cardiac Adaptations. Springer, New York.

Perez W, Mendez V, Vazquez N, Navarrete M, Konig HE. 2017. Gross anatomy of the heart of the alpaca (Vicugna pacos Linnaeus 1758). Anat Histol Embryol 47 (2): 110-118.

Rahma A, Hanadhita D, Prawira AY, Cahyadi DD, Supratikno, Maheshwari H, Satyaningtojas S, Agungpriyono S. 2017. Haematological study of fruit bat, Cynopterus titthaecheilus. Advances in Health Sciences Research. Proceedings of the 1st International Conference in One Health (ICOH 2017). Universitas Brawijaya, Malang, 1-2 March 2017. [Indonesian]

Reece JB, Urry LA, Cain ML, Wasserman SA, Minorsky PV, Jackson RB (eds.). 2014. Campbell Biology, 10th edition. Pearson Education, USA.

Riskin DK, Bahlman JW, Hubel TY, Ratcliffe JM, Kunz TH, Swartz SM. 2009. Bats go head-under-heels: the biomechanics of landing on a ceiling. J Exp Biol 212 (7): 945-953.

Rowlatt U. 1967. Functional anatomy of the heart of fruit-eating bat, Eidolon helvum, Kerr. J Morphol 123: 213-230. DOI: 10.1002/jmor.1051230303

Schinnerl M, Aydinonat D, Schwarzenberger F, Voigt CC. 2011. Hematological survey of common neotropical bat species from Costa Rica. J Zoo Wildl Med 42 (3): 382-391.

Shave R, Howatson G, Dickson D, Young L. 2017. Exercise-induced cardiac remodeling: Lessons from humans, horses, and dogs. Vet Sci 4 (1): 9. DOI: 10.3390/vetsci4010009.

Sohayati AR, Zaini CM, Hassan L, Eptein J, Suri AS, Daszak P, Sharifah H. 2008. Ketamine and xylazine combinations for short-term immobilization of wild variable flying foxes (Pteropus hypomelanus). J Zool Wildl Med 39 (4): 674-676.

Stephenson A, Adams JW, Vaccarezza M. 2017. The vertebrate heart: an evolutionary perspective. $J$ Anat 231 (6): 787-797. DOI: 10.1111/joa. 12687

Suyanto A. 2001. Kalong di Indonesia. Puslitbang Biologi LIPI, Bogor. [Indonesian]

Tadjalli M, Ghazi SR, Parto P. 2009. Gross anatomy of the heart in Ostrich (Struthio camelus). Iran J Vet Res 10 (1): 21-27.

Vandecasteele T, Vandevelde K, Doom M, Mulken EV, Simoens P, Cornillie P. 2013. The pulmonary veins of pig as an anatomical model for the development of new treatment for atrial fibrillation. Anat Histol Embryol 44 (1): 1-12. Doi: 10.1111/ahe.12099

Verhoeff K, Mitchell JR. 2017. Cardiopulmonary physiology: Why the heart and lungs are inextricably linked. Adv Physiol Educ 41: 348353. DOI: 10.1152/advan.00190.2016

Volpe JK, Makaryus AN. 2019. Anatomy, thorax, heart and pericardial cavity. Stat

Pearls. https://www.ncbi.nlm.nih.gov/books/NBK482452/. 